\title{
PERANAN SILATURAHIM DALAM KOMUNIKASI BISNIS PADA KESUKSESAN PENGUSAHA BATIK JETIS SIDOARJO
}

\author{
Althaf Aulia Chisty \\ Mahasiswa Program Studi S1 Ekonomi Islam-Fakultas Ekonomi dan Bisnis-Universitas \\ Airlangga \\ Email: auliaalthaf90@yahoo.co.id \\ Siti Inayatul Faiza \\ Departemen Ekonomi Syariah-Fakultas Ekonomi dan Bisnis-Unversitas Airlangga \\ Email : naya_viencha@yahoo.co.id
}

\begin{abstract}
:
This study aims to identify and explain how gathering in business communication that occurs in batik entrepreneurs at Jetis, Sidoarjo are able to play a role in achieving entrepreneurial success. This theme will be the basic reason for explaining the role of gathering in business communication on batik entrepreneurs' success that has been achieved at Jetis, Sidoarjo. The gathering is conducted between businessmen in local scope and outside of Sidoarjo, and the craftsmen and other employees.

This study used a qualitative approach with descriptive methods. Data was collected through documentation, interviews, and direct observation to study the object. To test the validity of data, this study uses three triangulations such as triangulation of sources, theories, and methods.

The research result showed that gathering in business communication conducted by batik entrepreneurs at Jetis, Sidoarjo, intended for the survival and success in batik entrepreneurship, as well as in the context of observance. Implementation gathering conducted in jetis, Sidoarjo's batik entrepreneurship is the formation of batik association in Sidoarjo, beside that gathering also help the entrepreneurs to made business collaborations between other batik entrepreneurs and create working atmosphere of kinship. It helps the entrepreneur to developing their business and achieve success.
\end{abstract}

Keywords: silaturahim, and Business Communication, Success, Batik Entrepreneurs.

\section{Pendahuluan}

\section{A. Latar Belakang}

Permasalahan

dibidang

perekonomian sangat kompleks terutama pengangguran dan kemiskinan. Lapangan pekerjaan yang terbatas menyebabkan meningkatnya tingkat pengangguran di Indonesia pada umumnya dan daerah-daerah pada khususnya. Banyaknya pengangguran secara otomatis menyebabkan timbulnya kemiskinan di masyarakat. Indonesia merupakan mayoritas penduduknya Islam dan berpedoman pada Nabi Muhammad SAW yang juga merupakan wirausahawan yang sukses dan akan membuat setiap masyarakat berpikir dan berupaya lebih dalam menghadapi tantangan hidup, dan menuntut masyarakat untuk berinovasi

dalam menjaga kualitas hidup serta mencari nafkah.

Rowe (2004) menyimpulkan, pemikiran yang inovatif akan menarik bakat lain yang selanjutnya merangsang kreatifitas dan meningkatkan kemampuan 
untuk berkompetisi. Oleh karena itu, salah satu pilihan yang dianggap tepat untuk menjawab tantangan kondisi tersebut adalah dengan mengembangkan pola hidup mandiri, dan hal itu dapat terjadi dengan berwirausaha. Berwirausaha merupakan cara yang tepat, bagi seseorang untuk bisa mengeluarkan ide dan kreatifitas yang muncul dari diri seseorang tanpa terbelenggu oleh aturanaturan struktural yang muncul jika menjadi seorang karyawan (Buchari Alma, 2011). ). As'ad (2003: 12) mendefinisikan kewirausahaan sebagai kemampuan dan sikap mandiri, kreatif, inovatif, ulet, berpandangan jauh ke depan, pengambilan resiko yang sedang dan tanpa mengabaikan kepentingan orang lain dalam bidangnya atau masyarakat.

Dalam Islam berwirausaha mempunyai proporsi yang spesial, Rasulullah SAW adalah Sang Manusia agung layak jadi Prototype Bussinessman sejati.(Afzalurrahman, 2000). Tujuan berwirausaha menurut Islam dan risalah yang di bawa Nabi Muhammad SAW ialah untuk menegaskan, mengenalkan dan bahkan memperluas aktivitas dakwah dan penyebaran syariat Islam. Sesuai sabda Nabi Muhammad berikut ini:

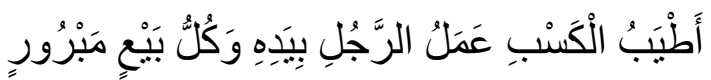

At\}yabu kasbi a'malurrojuli biyadihi bay'i mabruri.

"Sebaik-baik pekerjaan adalah pekerjaan seorang pria dengan tangannya dan setiap jual beli yang mabrur." (HR. Ahmad, Al-Bazzar, Ath-Thabrani).
Spirit yang dibawa dalam setiap aktivitas Islam tidak terkecuali seperti wirausaha adalah ibadah. Salah satu aktivitas yang sangat di anjurkan dalam Islam adalah silaturahim. (Alma dan Priansa, 2009).

Seperti difirmankan Allah dalam surat Muhammad (47): 22-23 :

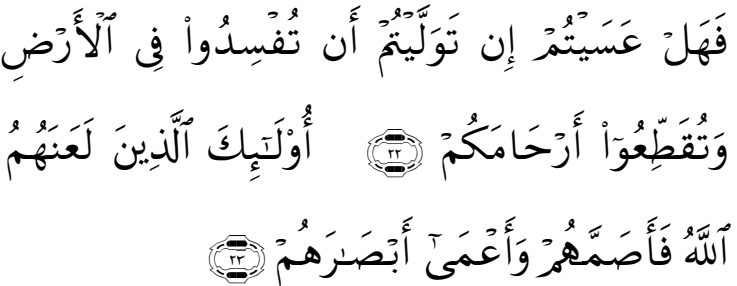
Fahal 'asaytum in tawallaytum an tufsidū fi al-ardi watuqațiti'u arhāmakum. Ulāikallīina la'anahumullāhu faaşammahum wa-a'mā abşārahum.

Maka Apakah kiranya jika kamu berkuasa kamu akan membuat kerusakan di muka bumi dan memutuskan hubungan kekeluargaan? (22). Mereka Itulah orangorang yang dila'nati Allah dan ditulikanNya telinga mereka dan dibutakan-Nya penglihatan mereka (QS. Muhammad : 22-23) (Depag, 2005).

Konsep berwirausaha yang ditawarkam Islam (Al-quran) tidak sematamata hubungan antar manusia tetapi juga mengupayakan sinergi keseimbangan antara kehidupan duniawi dan ukhrawi sebagai manisfestasi dari ibadah (Faizah, 2009:36). Berwirausaha tidak lepas dari hubungan manusia dengan manusia, dan manusia dengan lingkungannya hal itu tergambar dari konsep ibadah silaturahim. Para wirausahawan yang telah berhasil dengan gemilang mengakui pentingnya peranan 
orang lain dalam kesuksesannya. Berhubungan dengan para mitra bisnis bisa dilakukan dengan bersilaturahim dengan mengedepankan rasa ikatan persaudaraan. Sedangkan pengertian mitra bisnis adalah partner kerjasama bisnis yang saling menguntungkan antar pelaku bisnis. (Basrowi, 2011)

Kegiatan wirausaha dengan tidak mengutamakan laba dan omset namun mengutamakan ibadah di dalamnya yaitu silaturahim, maka hal itu akan menjadi nilai tersendiri. Melakukan korelasi antara silaturahim antar mitra bisnis terhadap wirausaha sangat efektif karena sebagai pintu masuk dalam hal mengembangkan wirausaha, karena dengan silaturahim membentuk sebuah relasi (Sofyan, 2011).

Indonesia merupakan negara yang padat penduduk dan kaya akan kultur budaya. Keanekaragaman budaya membuat penduduk Indonoesia memanfaatkan sebagai peluang untuk berwirausaha. Salah satu banyaknya budaya adalah batik dan dimanfaatkan penduduk Indonesia sebagai peluang untuk berwirausaha, pada Oktober 2009, UNESCO (United nation educational, scientific and cultural organization) mengukuhkan tradisi batik sebagai salah satu budaya warisan dunia asli Indonesia. Banyaknya muncul pengrajin batik di daerah daerah membuat tumbuhnya banyak UKM batik di Indonesia. Salah satunya di Sidoarjo, berpusat di Kampung jetis Sidoarjo yang dibawa oleh Mbah Mulyadi (Keturunan Raja Kediri). Sempat vakum karena tidak ada generasi yang meneruskan, namun pada tahun 1950 dihidupkan oleh lbu Widiasih (Keturunan pertama dari Mbah Mulyadi) sampai akhirnya pada tahun 1970-an para pegawainya memberanikan diri untuk membuka usaha sendiri dan menjadi pencaharian utama warga Jetis hingga sekarang.

Berdasarkan uraian tersebut maka penulis muncul keinginan untuk melakukan penelitian bagaimana silaturahmi dapat meningkatkan kesuksesan dalam berwirausaha. Maka didapatkan judul "Peranan Silaturahim Dalam Komunikasi Bisnis Pada Kesuksesan Pengusaha Batik di Jetis Sidoarjo".

\section{B. Rumusan Masalah}

1. Bagaimana silaturahim di dalam komunikasi bisnis antar mitra bisnis serta para pegawai dan pengrajin di Jetis Sidoarjo dapat meningkatkan kesuksesan berwirausaha?

\section{Tujuan Penelitian}

Dari hasil penelitian penulis mempunyai tujuan:

1. Untuk mengetahui seberapa besar peran konsep silaturahmi dilaksanakan dalam berwirausaha.

\section{Manfaat Penelitian}

Adapun manfaat yang diharapkan penelitian ini adalah:

1. Sebagai pengajaran untuk calon wirausahawan untuk mempelajari cara perdagangan yang benar dan baik. 
2. Sebagai masukan untuk dapat melakukan kegiatan wirausaha yang sukses, dengan konsep ibadah.

3. Untuk mengetahui keuntungan apa saja yang diperoleh wirausahawan dalam berwirausaha dengan menggunakan konsep silaturahim dalam hubungan manusia dengan manusia.

4. Menambah khasanah ilmu pengetahuan tentang berwirausaha secara Islami.

\section{E. Sistematika Skripsi}

$B A B$ I: Pendahuluan

BAB II : Tinjauan Pustaka

BAB III : Metode Penelitian

BAB IV: Pembahasan

BAB V: Simpulan Dan Saran

\section{Landasan Teori}

\subsubsection{Komunikasi Bisnis}

Menurut William C. Himstreet dan Wayne Murlin Baty dalam Bussines Communications: Principles and Methods (1990) komunikasi adalah suatu proses pertukaran informasi antar individu melaui sistem yang biasa (lazim) baik dengan komunikasi ini paling tidak melibatkan dua orang atau lebih dengan menggunakan cara-cara berkomunikasi yang biasa dilakukan seseorang seperti melalui lisan, tulisan, maupun sinyal-sinyal non-verbal. Sedangkan komunikasi bisnis adalah komunikasi yang biasa digunakan dalam dunia bisnis yang mencakup berbagai macam bentuk komunikasi baik komunikasi verbal maupun non-verbal. (Djoko 2003:61)
Dalam menjalankan roda bisnis semua tidak lepas dari organisasi, baik itu organisasi dalam skala kecil maupun skala besar. Organisasi adalah sekelompok masyarakat yang saling berkerjasama untuk mencapai suatu tujuan tertentu, dan komunikasi adalah perekat yang memungkinkan kelompok masyarakat tersebut secara bersama-sama dapat melakukan fungsinya dengan baik. Secara umum, komunikasi mempunyai dua fungsi penting dalam organisasi: (1) Komunikasi memungkinkan orang-orang untuk saling bertukar informasi; (2) komunikasi membantu untuk menghubungkan sekelompok anggota dalam organisasi yang terpisah dari anggota lainnya (Djoko. 2005: 23) . Dari tiga tujuan tersebut informing, persuading, dan collaborating dan ditambah dengan komunikasi di dalam suatu organisasi yang baik dan sejalan dengan niat beribadah melalui silaturahim maka feedback yang diterima akan positif.

Silaturahim ialah suatu komunikasi antar manusia yang dilakukan dengan tujuan untuk mempererat persaudaraan dan mempertebal ikatan batin seseorang terhadap sesama. Dengan begitu komunikasi akan efektif apabila terjadi pemahaman yang sama dan merangsang pihak lain untuk berpikir dan melakukan sesuatu, dengan ikatan batin yang erat maka pemahaman dalam komunikasi akan mudah terjalin (Dewi, 2006:14). 


\subsubsection{Silaturahim}

Silaturahim ialah suatu komunikasi antar manusia yang dilakukan dengan tujuan untuk mempererat persaudaraan dan mempertebal ikatan batin seseorang terhadap sesama. Kalimat silaturahim dari bahasa Arab, tersusun dari dua kata silah yaitu, alaqah (hubungan) dan kata alrahmi yaitu, Al-qarabah (kerabat) atau mustauda Al-Janin artinya "rahim atau peranakan". (Al-Munawir, 1999: 1638,1668) kata Al-rahim seakar dengan kata AlRahmah dari kata rahima "menyayangimengasihi" jadi secara harfiah silaturahim artinya menghubungkan tali kekerabatan, menghubungkan kasih sayang. Nabi Muhammad SAW bersabda:

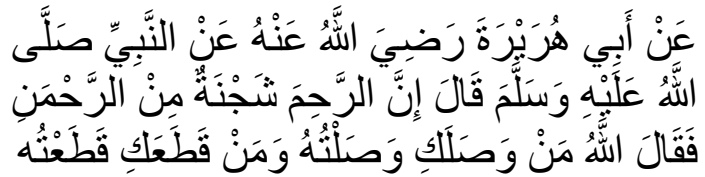
a $\mid n$ aby> hurayra ta rad\}iyal-Lahu a\}nhu a\}nnabii> s\}allal-Lahu a\}laihi wa sallam. Qala> innar-rohima shajna minr-rohman faqalal-Lahu man wa s\}alaki wa s\}altuhu waman qat\}aa\}ki qat\}a |'tuh.

Dari Abu Hurairah Ra, Nabi Saw bersabda : Sesungguhnya rahim itu diambil dari nama Allah yaitu Al-Rahman, Allah Swt berkata kepada rahim, "Barang siapa yang menyambungkanmu (berbuat baik kepada mu) maka aku akan berbuat baik kepadamu, barang siapa yang memutuskanmu aku akan memutuskannya (HR Bukhari, dalam bahreizy).

Sebetulnya yang dimaksud silaturahim adalah hubungan keluarga berdasarkan keturunan atau pernikahan.
Dan yang dimaksud menyambung kembali hubungan silaturahim yang terputus apabila ada permusuhan dalam hubungan keluarga lalu ada upaya untuk menyambung kembali. Menurut Islam, orang yang bersikap buruk pada orang yang berusaha menyambung hubungan keluarga, tidak akan masuk surga karena sikapnya ini. (Syais, 2009).

Orang yang memutuskan tali silaturahim maka rahmat Allah tidak akan sampai padanya berarti dia tidak bisa merasakan kasih sayang Allah. Hal ini sesuai Firman Allah (QS. An-nisaa:1):

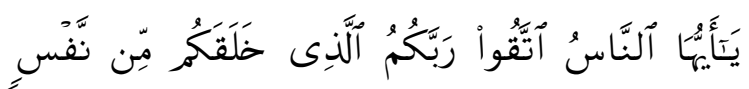

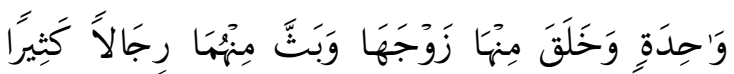

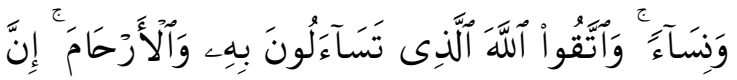

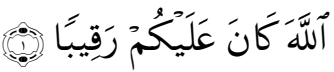
yā ayyuhā alnnāsu ittaqū rabbakumu allażì khalaqakum min nafsin wāhidatin wakhalaqa minha zawjahā wabaśśa minhumārijālan kaśhīran wanisān waittaqū Allāha allażī tasā-alūna bihi wāl-arhāma inna Allāha kāna 'alaykum raqīban.

"Hai sekalian manusia, bertakwalah kepada Tuhan-mu yang telah menciptakan kamu dari seorang diri, dan dari padanya Allah menciptakan istrinya; dan dari pada keduanya Allah memperkembang biakkan laki-laki dan perempuan yang banyak. Dan bertakwalah kepada Allah yang dengan (mempergunakan) nama-Nya kamu saling meminta satu sama lain, dan (peliharalah) hubungan silaturahim. Sesungguhnya 
Allah selalu menjaga dan mengawasi kamu."(QS. An-nisa:1. (Depag, 2005).

Ayat di atas memberikan arahan bagi muslim agar selalu merasa diawasi oleh Allah Yang Maha Mengawasi. Hal itu sesuai penafsiran yang disampaikan Ibnu Katsir bahwa penyebutan manusia itu dari asal penciptaan manusia itu sendiri. Untuk itu Allah menyebut bahwa asal penciptaan manusia adalah dari satu ayah dan satu ibu, agar sebagian mereka berkasih sayang. (Ibnu Katsir, 2010).

\subsubsection{Manfaat Silaturahim}

Manfaat silaturahmi tidak hanya mempererat persaudaraan, tetapi juga dapat memperluas rezeki, memperpanjang umur, dikenang kebaikannya, diperpanjang umurnya. Hal ini sesuai sabda nabi.

$$
\text { مَنْ أَحَبَّ أَنْ يُبْسَطَ لَلهُه فِي رِزْقِهِ، }
$$

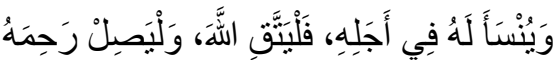

Man aakhabba aanyu\#bsatu\# lahu\# fis ajalihi falyatti'l-Allaha walayas\}ill

rokhimahu.

"Barang siapa yang senang dilapangkan rezekinya dan diakhirkan ajalnya (dipanjangkan umurnya), maka hendaklah ia menyambung tali silaturahmi (Bukhari dan muslim)".

Selain itu Allah SWT berfirman :

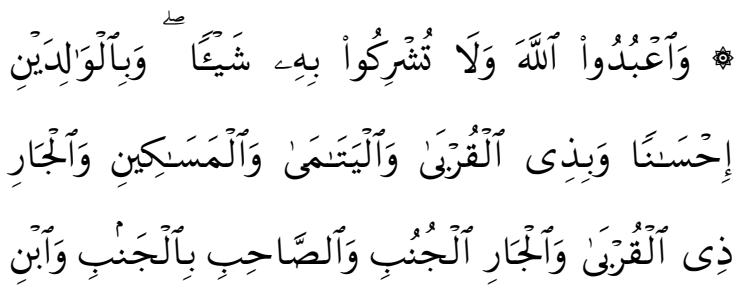

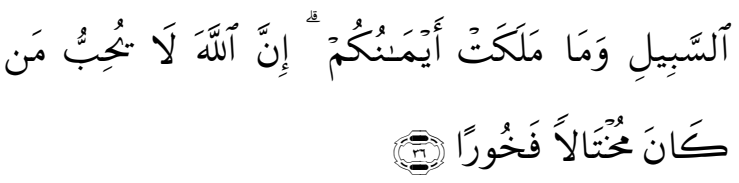

Wau'budū allāha walā tusyriku bihi syayan wabialwālidayni ihsānan wabiżi alqurbā waalyatāmā waalmasākīni waaljāriżil qurba waaljāri aljunubi alşşāhibi bialjanbi waibni alssabili, wamā malakat aymānukum, innallāha lā yuhibbu man kāna mukhtālan fakhūrān.

"Sembahlah Allah dan janganlah kamu mempersekutukan-Nya dengan sesuatupun. dan berbuat baiklah kepada dua orang ibu-bapa, karib-kerabat, anakanak yatim, orang-orang miskin, tetangga yang dekat dan tetangga yang jauh, dan teman sejawat, Ibnu sabil dan hamba sahayamu. Sesungguhnya Allah tidak menyukai orang-orang yang sombong dan membangga-banggakan diri." (QS: An-nisa': 36) (Depag, 2005).

Allah memerintahkan kepada hamba-hamba-Nya agar sealu menyembah Dia semata, tiada sekutu bagi Dia. Karena sesungguhnya Dialah Yang Maha Pencipta, Maha Pemberi rezeki, Maha Pemberi nikmat. Dialah Yang Maha Pencipta, Maha Pemberi rezeki, Maha Pemberi nikmat. Maka hendaklah menyembah kepada-Nya dan selalu mengasihi ibu dan bapak karena tidak akan ada kerabat kecuali dengan perantara mereka. Oleh sebab itu, saling berbuat baiklah dengan sesama manusia baik dari bentuk perbuatan maupun perkataan (Ibnu Katsir, 2010). 


\subsubsection{Membangun Silaturahim}

Meskipun manfaat silaturahim sangat banyak, namun bukan mencari manfaat itu yang dicari tetapi niat karena Allah. Dengan begitu selain manfaat dan juga diluaskan rezeki maka juga akan mendapatkan pahala dari Allah SWT. tidak perlu untuk menafikan manfaat dunia saja. Manfaat dunia bisa didapatkatapi bukan hal utama. Dan yang perlu diperhatikan bahwasanya bukan silaturahim yang memperluas rezeki tetapi Allah lah yang memperluas rezeki sebagai balasan terhadap niat ibadah yang diniatkan mulai dari awal. Silaturahim harus ditanamkan dengan cinta, cinta sesama mahkluk Allah dan muslim karena setiap muslim adalah saudara.(Anna dan Milah, 2012). Hal tersebut sesuai dengan firman Allah (QS. Al-Hujurat:10).

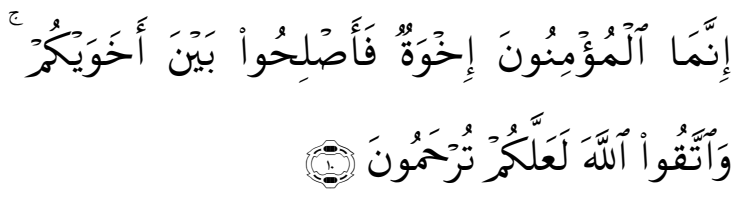

Innamā almu'minūna ikhwatun fa-aşlihū bayna akhawaykum wattaqū allāha la'allakum turhamūna.

"Orang-orang beriman itu Sesungguhnya bersaudara. sebab itu damaikanlah (perbaikilah hubungan) antara kedua saudaramu itu dan takutlah terhadap Allah, supaya kamu mendapat rahmat"(QS:AL-Hujurat:10).(Depag, 2005).

Dari ayat tersebut tersirat bahwa sangat penting menjalin persaudaraan dengan sesama muslim. Persaudaraan yang kokoh akan memudahkan semua urusan manusia. Tentunya jika kedua pihak menjaga persaudaraan tersebut dengan baik, pasti akan memberi manfaat dan keutamaan yang banyak (Syais, 2009).

\subsubsection{Kewirausahaan}

\subsubsection{Kewirausahaan Secara Umum}

Menurut Kamus Besar Bahasa Indonesia, wirausaha adalah orang yang pandai atau berbakat mengenali produk baru, menentukan cara produksi baru, menyusun operasi untuk mengadakan produk baru, mengatur permodalan operasinya serta memasarkannya. (Diknas, 2005).

Dalam lampiran Keputusan Menteri Koperasi dan Pembinaan Pengusahan Kecil Nomor 961/KEP/M/XI/1995, dicantumkan bahwa: 1. Wirausaha adalah orang yang mempunyai semangat, sikap dan kemampuan kewirausahaan. 2. Kewirausahaan adalah semangat, sikap, perilaku dan kemampuan seseorang dalam menangani kegiatan yang mengarah pada upaya mencari, menciptakan serta menerapkan cara kerja, teknologi dan produk baru dengan meningkatkan efisiensi dalam rangka memberikan pelayanan yang lebih baik dan atau memperoleh keuntungan yang lebih besar. Jadi wirausaha itu mengarah kepada orang yang melakukan usaha/kegiatan sendiri dengan segala kemampuan yang dimilikinya.

Pada dasarnya Islam tidak menjelaskan secara rinci tentang kewirausahaan, namun ada beberapa 
hadits yang menjelaskan tentang pintu rizki bagi orang berwirausaha. Dalam Hadits Nu'aim bin 'Abdur Rahman meriwayatkan sebagai berikut: "Sembilan dari 10 pintu rezeki ada dalam perdagangan dan sepersepuluh ada dalam beternak domba." (HR. Sa'id bin Manshur). dan penyebaran Islam di indonesia sendiri merupakan agama yang di bawa pedagang.

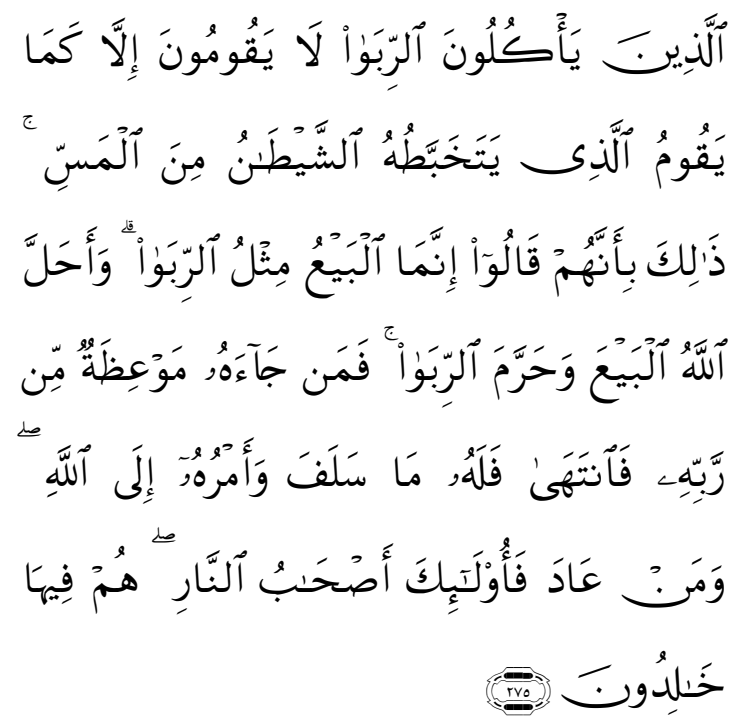

allażīna ya/kulūna alrribā lā yaqūmūna illā kamā yaqūmu allażì yatakhabbațuhu alsysyayțānu mina almassi żālika biannahum qālū innamā albay'u miślu alrribā wa-ahalla allāhu albay'a waharrama alrribā faman jā-ahu maw'izatun min rabbihi faintahā falahu mā salafa wa-amruhu ilā allāhi waman 'āda faulā-ika ash-hābu alnnāri hum fihā khālidūna.

"orang-orang yang makan (mengambil) riba tidak dapat berdiri melainkan seperti berdirinya orang yang kemasukan syaitan lantaran (tekanan) penyakit gila. Keadaan mereka yang demikian itu, adalah disebabkan mereka berkata (berpendapat), Sesungguhnya jual beli itu sama dengan riba, Padahal Allah telah menghalalkan jual beli dan mengharamkan riba. orang-orang yang telah sampai kepadanya larangan dari Tuhannya, lalu terus berhenti (dari mengambil riba), Maka baginya apa yang telah diambilnya dahulu (sebelum datang larangan); dan urusannya (terserah) kepada Allah. orang yang kembali (mengambil riba), Maka orang itu adalah penghuni-penghuni neraka; mereka kekal di dalamnya"(Qs Al Baqarah(2):275) (Depag, 2005).

Dalam surah Al Baqarah ayat 275 di atas dijelaskan bahwa Allah swt telah menghalalkan kegiatan jual beli dan mengharamkan riba. (Syafi'e, 2011).

Konsep wirausaha yang diajarkan Islam bukan hanya mencari keuntungan sebesar-besarnya dengan menggunakan modal yang sekecil-kecilnya tetapi merupakan sebuah ibadah karena berwirausaha adalah wadah untuk berbuat baik kepada sesama manusia.

\subsubsection{Kunci Sukses Berwirausaha}

Jalan menuju wirausaha sukses menurut Murphy dan Peck (1908: 8) menggambarkan delapan anak tangga untuk mencapai puncak karir delapan anak tangga itulah yang digunakan oleh wirausaha untuk mengembangkan profesinya

1. Kerja Keras (Capacity for hard work

2. Berkerjasama ( Getting Things Done with) 
3. Penampilan yang baik (Good appearance)

4. Pandai membuat keputusan (making sound decision)

5. Yakin (Self Confidence)

6. Mau nenambah ilmu pengetahuan (College Education)

7. Ambisi untuk maju (ambition drive)

8. Pandai berkomunikasi (Ability to communicate)

\subsubsection{Kunci Sukses Berwirausaha Secara} Islam

Sejak masa kehidupan Rasulullah SAW hingga sekarang, umat Islam telah sepakat atas dibolehkannya bisnis dan bermuamalah dengannya. Bahkan Islam telah telah mensyariatkan beberapa kaidah dan prinsip yang wajib diikuti dan dilaksanakan agar mencapai sukses dalam bisnis, berdagang, atau jual beli. Kamal Ali (2007:12) menerangkan kaidahkaidah atau kiat-kiat bisnis agar memetik buah dari kesuksesan itu, antara lain berikut:

1. Niat yang ikhlas karena Allah.

2. Mengetahui hukum-hukum bisnis

3. emilih bidang bisnis atau perdagangan yang halal.

4. Bersikap lapang dada dalam berbisnis

5. Banyak Sedekah.

6. Menghindari riba.

7. Berbisnis jangan sampai melalaikan dari mengingat Allah SWT.

\subsubsection{Konsep Sukses}

Sukses adalah suatu impian atau tujuan yang diinginkan seseorang yang telah tercapai melalui usaha dan kerja keras yang telah dijalaninya dan dalam mencapai kesuksesan dan keinginan tersebut berupa hal positif baik untuk diri sendiri maupun untuk orang lain (Alvin, 2012).

Jika menggunakan sebuah perumpamaan tentang seseorang yang ingin pergi ke suatu tempat dengan mengendarai kendaraan, pasti seseorang itu tidak masuk ke kendaraan itu begitu saja. Menyalakan kendaraan tersebut, menginjak gas lalu menuju ke tempat mana yang dituju. Tugas kendaraan itu adalah membawa penumpang lebih cepat daripada menggunakan kekuatan diri sendiri. Itulah sebabnya seseorang begitu menyukai kendaraannya.

Sama halnya dalanm meraih kesuksesan. Seseorang akan menjadi lebih mudah jika tahu tempat mana yang akan dituju dengan kendaraan tersebut. Ukuran sukses bisa berupa apa saja, dimana saja, kapan saja karena semuannya berujung saat merasakan kebahagiaan. Dan kebahagiaan itu pada akhirnya akan bermuara di hati.

\subsubsection{Kesuksesan Menurut Pandangan} Islam

Tidak bisa dipungkiri bahwa materi memang melengkapi kesuksesan seseorang. Akan tetapi, sejatinya materi hanyalah sebagian kecil dari kesuksesan atau pelengkap kesuksesan dan bukan merupakan satu-satunya kesuksesan, itupun jika materi dikelola dengan petunjuk agama. Jika tidak, justru 
kebangkrutan yang akan didapat dan bukan kesuksesan

Kesuksesan dalam Islam lebih terfokus pada tujuan-tujuan besar dalam hidup ini yang dikaitkan dengan masalah keimanan kepada Allah SWT dan 'ubudiyyah (penghambaan diri kepadaNya) yang sejati (Al-Qu'ayyid, 2005:10). Beliau menjelaskan bahwa tujuan utama dari kehidupan manusia di bumi ini adalah untuk mewujudkan dua macam kesuksesan, yaitu kesuksesan di dunia dan kesuksesan di akhirat.

Dijelaskan dalam Al-Quran surat alQashash ayat 77:

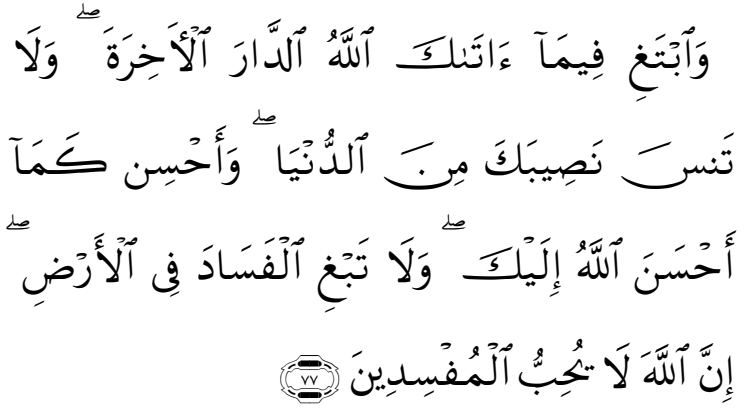

Waibtagi fimāa ātāka allāhu alddāra alākhirata walā tansa naşibaka mina alddunyā wa-ahsin kamā ahsana allāhu ilayka walā tabgi alfasāda fī al-ardi inna allāha lā yuhibbu almufsidina.

"Dan carilah pada apa yang telah dianugerahkan Allah kepadamu (kebahagiaan) negeri akhirat, dan janganlah kamu melupakan bahagianmu dari (kenikmatan) duniawi dan berbuat baiklah (kepada orang lain) sebagaimana Allah telah berbuat baik, kepadamu, dan janganlah kamu berbuat kerusakan di (muka) bumi. Sesungguhnya Allah tidak menyukai orang-orang yang berbuat kerusakan." (QS. Al-Qashash: 77) (Depag, 2005).

Sedangkan makna sukses menurut Nabi Muhammad SAW lebih simpel sekaligus dalam. Yaitu apabila seseorang bisa lebih baik daripada hari kemarin.

Arwani (2010:15-17), membagi beberapa sisi kesuksesan, yaitu:

1. Finansial

2. Intelektual

3. Sosial

4. Fisik

5. Spiritual

Arwani (2010:17), menyatakan bahwa jika kelima sisi tersebut tercapai maka seorang muslim dapat dikatakan sukses sejati atau sukses dunia akhirat.

\subsection{Penelitian Sebelumnya}

Penelitian ini merujuk kepada beberapa hasil kajian penelitian sebelumnya sebagai bahan referensi. Ahlam (2013) telah melakukan penelitian dengan judul "Kunci Sukses Bisnis Keturunan Arab di Kawasan Ampel Surabaya". Penelitian ini dilakukan untuk mengetahui kunci sukses berbisnis secara general di kawasan ampel Surabaya. Kesimpulannya adalah hasil analisis menunjukan bahwa kesuksesan dalam berbisnis oleh keturunan Arab di Ampel Surabaya adalah dengan menjalankan sunnatullah bersedekah

Penelitian lainnya juga dilakukan oleh Labbaika (2013) yang melakukan penelitian dengan judul "Dampak Ketaqwaan Dalam Kesuksesan (Studi Kasus: Pengusaha Fesyen di Surabaya)". 
Penelitian ini ingin mengetahui sikap ketaqwaan seorang wirausahawan dapat mendukung kesuksesan dalam berwirausaha. Kesimpulan dalam penelitian tersebut adalah bahwa kesuksesan bagi pengusaha fesyen pada umumnya lebih terkait dengan kesuksesan spiritual. Menurut pengusaha fesyen ketika seseorang telah tercapai kesuksesan spiritual, maka kesuksesan seperti finansial, sosial, intelektual, dan fisik terangkum di dalamnya.

Persamaan penelitian yang dilakukan oleh Ahlam (2013), penelitian Labbaika (2013), dan penelitian ini adalah ingin mengetahui kiat sukses berwirausaha secara Islami. Dan perbedaan penelitian ini dengan yang dilakukan oleh Ahlam (2013) dan Labbaika (2013) adalah penelitian ini meneliti bagaimana peranan silaturahmi dengan mitra bisnis pada kesuksesan berwirausaha.

\section{a. Kerangka Berpikir}

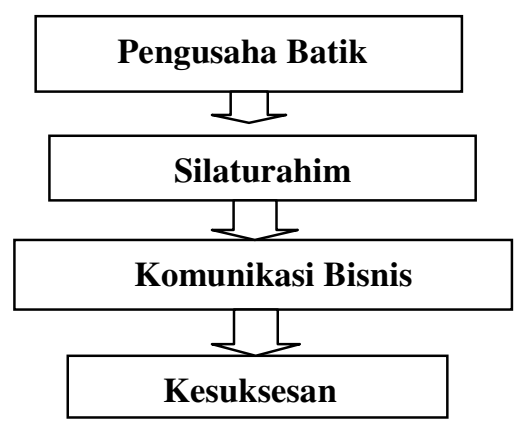

\section{b. Proposisi}

Proposisi dalam penelitian ini adalah:

1. Membangun konsep silaturahmi di dalam berwirausaha dengan mitra bisnis dapat menciptakan rasa saling percaya dalam berbisnis dan bisnis menjadi berkembang.
2. Dengan membangun konsep silaturahmi dengan para pegawai dan pengrajin dapat menciptakan lingkungan kerja yang penuh kekeluargaan dan kondusif. Hal itu, berakibat pada kinerja yang maksimal para pengusaha.

\section{Metode Penelitian}

\section{a. Pendekatan dan Jenis Penelitian}

Pendekatan yang digunakan dalam penelitian ini adalah pendekatan kualitatif deskriptif. Pada pendekatan ini, peneliti membuat suatu gambaran kompleks, menyusun catatan lapangan, dan masuk ke dalam setiap analisis dan wawasan. Alasan penggunaan metode penelitian kualitatif deskriptif karena penelitian ini tidak bertujuan untuk mencari hubungan atau pengaruh signifikasi melainkan lebih fokus untuk menguraikan analisa.

\section{b. Ruang Lingkup penelitian}

Ruang lingkup penelitian ini hanya terbatas terhadap pengamalan nilai silaturahmi oleh pengusaha batik sehingga akan menghasilkan sebuah kesuksesan oleh pengusaha tersebut. Pengamalan nilai silaturahim dalam hal ini mengenai bagaimana seorang wirausahawan mampu mempraktekan silaturahim antar pengusaha, pengrajin, dan pegawai untuk mencapai kesuksesan dalam berwirausaha serta dapat membuka peluang usaha baru atau memperluas usahanya. 


\section{c. Jenis dan Sumber Data}

Jenis data yang digunakan dalam penelitian ini adalah :

1. Data Primer

2. Data Sekunder

Peneliti menggunakan teknik purposif sampling untuk menentukan informan.

\section{d. Prosedur pengumpulan Data}

1. Dokumentasi.

2. Wawancara

3. Observasi Langsung

$$
\text { Selain itu, Yin }
$$

menyebutkan tiga prinsip pengumpulan data guna menunjang sumber bukti tersebut, yaitu menggunakan multisumber bukti. Multisumber bukti dilakukan agar penelitian akan lebih relevan daripada menggunakan satu sumber bukti saja, multisumber bukti itu adalah triangulasi. Penelitian ini menggubnuakan 3 triangulasi yaitu:

1. Triangulasi Sumber yang menggunakan berbagi sumber seperti arsip, wawancara, dan observasi.

2. Triangulasi metode untuk meneliti suatu hal, seperti metode wawancara dan metode observasi.

3. Triangulasi Teori penggunaan berbagai teori yang berlainan untuk memastikan bahwa data yang dikumpulkan sudah memenuhi syarat.

\subsection{Teknik Analisis}

Teknik analisis dalmn penelitian ini dilakukan denngan metode deskriptif. Teknik ini dipilih untuk menggambarkan atau mendeskripsikan sebuah situasi atau fenomena tentang silaturahim yang terjadi dalam wirausahawa batik di kampung Jetis Sidoarjo melalui fakta-fakta yang diperoleh dari data-data lapangan yang meliputi observasi langsung, wawancara, rekaman arsip, dan dokumentasi yang dilakukan dalam konteks kehidupan nyata. Dari serangkaian penelitian tersebut akan menghasilkan kesimpulan akan situasi atau fenomena yang menjadi permasalahan dalam penelitian ini. Teknik analisis data dalam penelitian ini meliputi:

1. Reduksi Data

2. Penyajian Data

3. Kesimpulan dan Verifikasi

\section{Pembahasan}

\subsection{Gambaran Umum Objek Penelitian}

\subsubsection{Sejarah Batik Jetis Sidoarjo}

Keberadaan perusahaan batik Jetis Sidoarjo sudah berdiri sejak tahun 1675, dibawa oleh keturunan raja Kediri yang dikejar-kejar oleh penjajah dan lari ke Sidoarjo. Sayangnya sampai sekarang belum ada siapa sebenarnya pria yang dikenal dengan nama Mbah Mulyadi. Mbah Mulyadi mengawali berdagang di "Pasar Kaget" yang dikenal dengan nama pasar Jetis dan memberikan pelatihan pengajian dan keterampilan membatik.

Sempat vakum, Pada tahun 1950an usaha batik Jetis didirikan lagi oleh seorang wanita yang berbnama lbu Widiarsih (Bu Wida) dan banyak warga kampung Jetis waktu itu masih menjadi pekerjanya. 
4.1.2 Perkembangan UKM Batik Jetis Sidoarjo

Sidoarjo adalah salah satu kota yang memiliki potensi batik yang patut diperhitungkan, yang terkenal dengan nama "Kampoeng" Batik Jetis. Di "Kampoeng" Jetis, membatik telah menjadi bagian dari aktivitas sehari-hari dan telah menjadi tradisi budaya lokal masyarakat Jetis karena $90 \%$ warganya berprofesi pengrajin batik. Motif batik Jetis Sidoarjo terdiri dari berbagai macam flora dan fauna, seperti udang-bandeng, burung merak, burung cipret, kupu-kupu, kembang suruh, dan lain-lain. motif udang dan bandeng menjadi pakem batik khas Sidoarjo, karena Sidoarjo merupakan kota yang terkenal sebagai daerah penghasil udang dan bandeng.

Pada tanggal 16 April dibentuk Paguyuban Batik Sidoarjo (PBS) Ide pembentukan paguyuban ini berasal dari kaum muda Jetis yang memiliki harapan besar kepada kelestarian batik Jetis itu sendiri dan menjadi budaya setempat yang bisa dibanggakan.

\subsection{Hasil Penelitian}

\subsubsection{Data Penelitian}

Data penelitian merupakan
deskripsi secara umum mengenai
informan melalui hasil wawancara,
observasi, serta triangulasi yang dilakukan
dalam penelitian. Unsur silaturahim dalam
komunikasi bisnis ini adalah memberikan
informasi tentang dunia bisnis kepada
orang lain, memberikan persuasi yang
dalam hal ini berkaitan dengan negosiasi

dengan orang lain dalam bisnis, dan yang terakhir adalah kolaborasi yang berkaitan dengan melakukan kerja sama bisnis. Semua juga dengan niatan ibadah untuk mempererat persaudaraan dan mempertebal ikatan batin seseorang terhadap sesama, dan hal itu memudahkan dalam hal komunikasi dan menimbulkan efek positif.

Praktik informasi yang terjadi di dalam pengusaha batik Jetis Sidoarjo adalah ketika salah satu pengusaha mempunyai informasi adanya pameranpameran sebagai sarana untuk memasarkan batik dan disampaikan kepada pengusaha lain di dalam pertemuan rutin paguyuban dan informasi juga bisa diberikan dari pengusaha batik lain di luar Sidoarjo. Dan yang terakhir adalah praktik kolaborasi, dalam praktiknya pengusaha batik Jetis Sidoarjo dengan melakukan kerjasama dengan pengusaha batik daerah lain seperti mengkombinasikan dua corak batik daerah lain dengan corak batik khas Sidoarjo, selain itu kerja sama dilakukan dengan saling membantu untuk meningkatkan SDM pengrajin dan pegawai. Dari semua kegiatan yang dilakukan tersebut selalu didasarkan semangat yang sama yaitu kekelvargaan dan untuk kemajuan bersama demi melestarikan dan memperkenalkan batik khas Sidoarjo serta terciptanya pemahaman dalam komunikasi akan mudah terjalin. 


\subsubsection{Analisis Bahasan}

\subsubsection{Pola Silaturahim}

pola silaturahim yang dilakukan oleh pengusaha yang terwakili oleh beberapa informan menunjukan ada kekhasan tersendiri dari silaturahim yang dilakukannya. Kekhasan itu bisa dilihat dari beberapa konsep, yaitu:

a. Konsep Jarak Komunikasi, ada yang lingkup Sidoarjo dan ada yang di luar wilayah Sidoarjo.

b. Konsep Pola Silaturahim Dengan Media Sosial dan Teknologi Informasipola silaturahim yang ini sangat bermanfaat ketika menghubungkan interaksi antar pengusaha di luar wilayah Sidoarjo.

c. Konsep Pola Silaturahim di Internal Usaha Batik Informan. secara internal silaturahim antar pengusaha dan pengrajin dan pegawai lainnya lebih ke downword silaturahim.

\subsubsection{Upaya maintenance Pola} Silaturahim

Kegiatan silaturahim juga bermanfaat dalam hal pemikat emosional dengan suatu argumentasi atau dalam bentuk simpati kepada kolega bisnis. Dalam hal ini menggunakan atau memilih kata-kata yang sangat berpengaruh pada emosi seseorang misalnya kenyamanan, kepercayaan dan keamanan. Dengan seperti itu upaya maintenance pola silaturahim akan berjalan dengan lancar.

Dari jalinan silaturahim yang terjalin antara pengusaha dengan beberapa orang, golongan, kelompok dan pemerintahan manfaatnya sangat besar dalam upaya mencapai kesuksesan dan eksistensi usaha batik di Jetis Sidoarjo. Dan menimbulkan sinergi keseimbangan antara dimensi vertikal dan dimensi horizontal.

\section{Simpulan Dan Saran}

\section{a. Simpulan}

Dari jalinan silaturahim tersebut memunculkan kerjasama-kerjasama yang saling menguntungkan, dan kemudahankemudahan dikala menemui kesulitan dalam menjalankan usaha batik. Selain itu terciptanya suasana bisnis yang nyaman dan penuh kekeluargaan juga sangat membantu pengusaha dalam mencapai kesuksesan berwirausaha. Kesuksesan yang diraih bermacam dikelompokan menjadi 5 sisi kesuksesan menurut Arwani, yaitu: (1) Finansial, (2) Intelektual, (3) Sosial, (4) Fisik, (5) Spiritual. hal ini akan menimbulkan sinergi keseimbangan antara dimensi vertikal (Hablum Minallah) dan dimensi horizontal (Hablum Minannas).

\section{b. Saran}

Saran yang dapat penulis sampaikan dalam penelitan ini adalah:

1. Bagi pengusaha batik di Jetis Sidoarjo

a. jaringan komunikasi melalui jaringan silaturahim antar pengusaha dan pengrajin serta pegawainya yang bisa membentuk secara emosional saling mengikat, semua relasi saling menunjang usaha dan keberhasilan.

b. Silaturahim juga dilakukan dengan konsumen, hal itu di maksudkan agar 
menambah kepuasan pelayanan terhadap konsumen.

2. Bagi Pemerintah

Lebih ditingkatkan lagi jaringan silaturahim yang terjalin dengan para pengusaha dan stakeholder di wilayah kampung batik Jetis Sidoarjo dengan secara intens mengawasi dan terus mendukung program-program sebagai upaya keberlangsungan budaya batik khas Sidoarjo.

3. Bagi lingkungan akademisi

a. Agar dilakukan penelitian yang lebih mendalam mengenai manfaat silaturahim dengan konsumen dalam memuaskan konsumen yang menikmati manfaat dari produk yang dibelinya.

b. Agar melakukan penelitianpenelitian tentang bisnis Islami. Terutama masalah Silaturahim menyangkut kegiatan bisnis, pemasaran dan penjualan.

\section{DAFTAR PUSTAKA}

Afzalurrahman. 2000. Muhammad Sebagai Seorang Pedagang. Terjemahan dari Muhammad encyclopedia of seerah. Jakarta: Yayasan Swarna Bhumy.

Ahlam, Abdullah. 2013. "Kunci Sukses Bisnis Keturunan arab Di Kawasan Ampel surabaya". Skripsi tidak diterbitkan. Program Sarjana Universitas Airlangga.

Ali, Kamal. 2007. Berbisnis Dengan Cara Rasul. Bandung: Jembar.
Alma, Buchari dan Donni Juni Priansa. 2009. Manajemen Bisnis Syariah. Bandung:Alfabeta.

Al-Munawwir.1999. Kamus Arab-Indonesia Terlengkap. Edisi Kedua. Jakarta.

Al-Qu'ayyid, Ibrahim bin Hamd. 2005. 10 Kebiasaan Muslim yang Sukses. Jakarta: Maghfirah Pustaka.

Al-Quran dan Terjemahannya.2005. Departemen Agama Republik. Indonesia, Jakarta.

Al-raghib al-asfahani.2004. Mu'jam almufradat li Al-faz Al-quran, (online), (https://archive.org/details/Mufrad atalQuran-Raghib , diakses 10 Oktober 2013).

Anna, Mariana dan Milah Nurmilah. 2012. Berkah dan Manfaat Silaturahmi. Jakarta: Ruang kata.

Antonio,Muhammad Syafi'i. 2007. Muhammad SAW The Super Leader Super Manager. Jakarta: Prenada Media. Faisal. Lalu Muchsin Efendi.

Arwani, Ahmad. 2010. Kunci Sukses Berbisnis: Ala Rasullulah SAW. Jakarta: Inti Media.

Bahreizy, Hussein. 2001. Hadis Shohih Bukhari: Himpunan Hadis Pilihan. Surabaya: Al-Ikhlas.

Basrowi, 2011. Kewirausahaan Untuk Pegawai Tinggi Negeri. Cetakan pertama. Bogor: Ghalva Indonesia.

Chapra, M.Umer. 2000. "Islam Dan Tantangan Ekonomi". Cetakan Pertama, Jakarta, Gema Insani.

Dahlan, Abdullah. Asis. et. Al. 1996. Ensiklopedi Hukum Islam. IV. Jakarta: Ichtiar Baru Van Hoeve. 
Departeman Pendidikan Nasional.2005.

Kamus Besar Bahasa Indonesia.

Edisi Keempat, Jakarta.Gramedia Pustaka Utama.

Dewi, Sutisna. 2006. "Komunikasi Bisnis". Yogyakarta. CV ANDI OFFSET.

Drucker, Peter F. (1996). Inovasi dan kewiraswastaan. Erlangga, Jakarta.

Dumairy. 1997. Perekonomian Indonesia. Jakarta: Rineka Cipta.

Elfindri, dkk. 2010. "Minang Entrepreneurship, Filosofi Dan Rahasia Sukses Etis Minang Membangun Karakter Kewirausahaan". Jakarta, Badouse Media.

Faizah, Siti Inayah. 2012. Kewirausahaan Dalam Perspektif Agama dan Budaya (Study fenomenologi
Konstruktif Wirausahawan Etnis

Tionghoa Muslim).Surabaya.

Universitas Airlangga (2009).

Himstreet, William C; Baty, Wayne Murlin. Bussines Communications: Priciples and Methods. Boston : PWS-kent Publishing Company, 1990.

Jauhar, Ahmad Al-Mursi Husain. 2010. "Maqashid Syariah". Jakarta: Amzah

M. Wiratmo. 1996. Pengantar Kewiraswastaan, Kerangka Dasar Memasuki Dunia Bisnis.Yogyakarta. BPFE.

Moleoong. 1988. Metodelogi Penelitian Kualitatif. Bandung: PT. Rosdakarya. Muhammad, bin Abdullah.2010. Tafsir Ibnu Katsir.Surakarta: Pustaka Imam Syafi'i. 